\title{
Annual Report on External Quality Assessment of Blood Bank Tests in Korea (2013)
}

Young Ae Lim ${ }^{1}$, Jin Sook $\mathrm{Oh}^{1}$, Seog Woon Kwon', Kye Chul Kwon ${ }^{3}$, Shin Young Kim ${ }^{4}$, Kyung Un Park ${ }^{5}$, Hyun Jun Park ${ }^{2}$, Woon Heung Song, Duck Cho ${ }^{7}$, Tae Hyoun Um $^{8}$, Kwang Hur', and Sang Moo Han ${ }^{10}$, as Blood Bank Subcommittee, The Korean Association of Quality Assurance for Clinical Laboratory

${ }^{1}$ Department of Laboratory Medicine, Ajou University

Hospital, Suwon; ${ }^{2}$ Department ofLaboratory Medicine,

Asan Medical Center, Seoul;

${ }^{3}$ Department of Laboratory

Medicine, Chungnam University

Hospital, Daejeon; ${ }^{4}$ Department of Laboratory Medicine,

Severance Hospital, Seoul;

${ }_{5}^{5}$ Department of Laboratory

Medicine, Seoul National

University Bundang Hospital,

Seongnam; ${ }^{6}$ Department of

Biomedical Laboratory Science,

Shinhan University, Uijeongbu;

${ }^{7}$ Department of Laboratory

Medicine, Chonnam National

University Hwasun Hospital,

Hwasun; ${ }^{8}$ Department of

Laboratory Medicine, Inje

University Ilsan Paik Hospital,

Goyang; ${ }^{9}$ Blood Laboratory

Center Central, Korean Red

Cross, Seoul; ${ }^{10}$ Gyeonggi Red

Cross Blood Center Central,

Korean Red Cross, Suwon,

Korea

Corresponding author:

Young Ae Lim

Department of Laboratory Medicine, Ajou University School of Medicine, 164 World cup-ro, Yeongtong-gu,

Suwon 443-380, Korea

Tel: +82-31-219-5786

Fax: +82-31-219-5778

E-mail: limyoung@ajou.ac.kr

pISSN: 1225-097X

eISSN: 2288-7261
We report here the results of surveys for External Quality Assessment (EQA) of blood bank tests carried out in 2013. The proficiency testing specimens were prepared at Ajou University Hospital and sent to 548 and 545 institutes participating in the 1st and 2nd trial, respectively. Test items for the surveys were $\mathrm{ABO}$ grouping, $\mathrm{RhD}$ typing, crossmatching, direct antiglobulin test (DAT), antibody screening test, and antibody identification test. The response rates for the 1st and 2nd trials were $94.3 \%$ and $96.0 \%$, respectively. No answers were considered incorrect answers, and the average accuracy rates of different test items of the survey were as follows: $\mathrm{ABO}$ grouping, $98.9 \%$ to $100 \%$; $\mathrm{RhD}$ typing, $98.4 \%$ to $99.2 \%$; crossmatching, $94.4 \%$ to $100.0 \%$; DAT using polyspecific reagent, $94.5 \%$ to $99.7 \%$; DAT using IgG monospecific reagent, $94.7 \%$ to $98.8 \%$; DAT using C3d monospecific reagent, $91.3 \%$ to 98.6\%; unexpected antibody screening test, $90.9 \%$ to $100 \%$; and antibody identification test, $87.3 \%$ to $100.0 \%$. Overall, we obtained excellent survey results for the EQA of blood bank tests carried out in 2013, and the number of participating institutes was higher in 2013 than in 2012.

(J Lab Med Qual Assur 2014;36:55-63)

Key Words : Blood banks, Laboratory proficiency testing 


\section{Journal of LABORATORY MEDICINE and QUALITY ASSURANCE}

\section{Young Ae Lim et al • Annual Report on EQA in Blood Banks}

\section{서론}

혈액은행검사는 수혈 전에 시행하는 $\mathrm{ABO}$ 및 $\mathrm{RhD}$ 혈액형 검사, 비예기항체 선별 및 동정검사, 교차시험이 포함되어 있 다. 이들 검사의 정확성은 환자의 생명과도 직결되는 매우 중 요한 요소이다. 대부분 혈액은행에서 실시하고 있는 검사의 원 리는 적혈구와 혈장 혹은 혈청을 이용한 면역혈구응집법검사 이다. 그러나 이러한 검사들의 내부정도관리물질들은 널리 상 품화되어 있지도 않을뿐더러 상품화되어 있는 물질은 고가이 기 때문에 일반 검사실에서는 이들을 구입하여 사용하기보다 는 대부분 자가제조물질을 사용하고 있는 실정이다. 이러한 이 유로 혈액은행검사의 외부정도관리 참여는 검사의 신뢰도를 평가할 수 있는 매우 중요한 과정이라고 할 수 있다.

2013년 혈액은행 신빙도조사에는 2012년까지 신빙도조사 에 참여하였던 기관과〔1] 신규가입기관을 포함하여 모두 547 기관이 참여하였다. 이 기관들을 대상으로 교육을 강조하기 위 하여 혈액은행 업무에 필요한 실기와 강의 워크솝을 총 2 회 개 최하였다. 이에 저자들은 2013년에 혈액은행분과에서 실시한 $\mathrm{ABO}$ 혈액형검사, $\mathrm{RhD}$ 혈액형검사, 교차시험검사, 직접항글 로불린검사, 비예기항체 선별검사 및 항체동정검사 등 총 6 가 지 항목과 추가로 실시한 두 가지 종류의 시범항목에 대한 신 빙도를 조사하였고, 기관별 검사방법에 대한 결과와 실시하였 던 워크숍 개최의 사업내용을 보고하고자 한다.

\section{재료 및 방법}

\section{1. 참여기관}

2013년도 혈액은행 신빙도조사 대상기관은 2012년까지 신 빙도조사에 참여하였던 기관과 신규가입기관을 대상으로 하 였다. 2013년 5월과 11월 총 2차에 걸쳐 신빙도조사를 실시하 였으며, 1 차 548 기관, 2 차 545 기관에 검체를 발송하였다.

\section{2. 조사항목}

조사항목은 예년과 마찬가지로 $\mathrm{ABO}$ 혈액형검사. $\mathrm{RhD}$ 혈액 형검사, 교차시험검사, 직접항글로불린검사, 비예기항체 선별 검사 및 동정검사 등 6 가지 항목에 대한 신빙도조사를 실시하 였다 [1-5]. 시범항목으로 1회 때는 적혈구 $\mathrm{A} 1, \mathrm{H}$ 항원, 2회 때 는 2012년도에 용역연구로 시행하였던 $\mathrm{ABO}$ 항체역가검사를 시범항목으로 추가하였다.

1) $A B O$ 혈액형검사

$\mathrm{ABO}$ 혈액형검사는 $\mathrm{A}$ 형, $\mathrm{B}$ 형, $\mathrm{O}$ 형, $\mathrm{AB}$ 형 중 무작위로 검
체를 선별하여 혈구형검사와 혈청형검사가 가능하도록 매회 2 개의 $\mathrm{ABO}$ 혈구용과 2 개의 $\mathrm{ABO}$ 혈청용 검체를 제조하였다.

2) $D$ 혈액형검사

$\mathrm{D}$ 혈액형검사는 $\mathrm{ABO}$ 혈액형검사에 사용된 혈구를 이용하 여 검사하도록 하였다.

\section{3) 교차시험검사}

교차시험검사는 매회 3 종류의 검체를 이용하여 교차시험을 실시하게 하였는데 검체별로 실온식염수법, $37^{\circ} \mathrm{C}$ 알부민법, 항글로불린법 단계의 반응을 달리하여 3 단계를 모두 점검할 수 있도록 검체를 제조하여 발송하였다.

\section{4) 직접항글로불린검사}

직접항글로불린검사는 1 차와 2 차는 음성 결과와 양성 결과 를 나타내는 두 가지 유형의 검체를 발송하였다.

\section{5) 비예기항체 선별검사 및 동정검사}

비예기항체 선별검사 및 동정검사는 항체선별검사만 실시하 는 기관과 동정검사까지 실시하는 기관을 분류하여 검체가 발 송되었다. 즉, 비예기항체 선별검사만 실시하는 기관에는 2 종 류의 검체가 2 차에 걸쳐 운송되었으며, 비예기항체 동정검사 까지 실시한 기관은 3 종류의 검체가 2 차에 걸쳐 운송되어 총 4 검체에서 6 검체까지 검사를 실시하였다. 항체선별검사만을 실 시하는 기관에는 매회 음성인 검체와 양성인 검체를 발송하였 으며, 동정검사를 실시하는 기관에는 매회 음성인 검체 1 개와 양성인 검체 2 개를 발송하였다. 비예기항체 동정용 양성 검체 로 1차는 anti-D와 anti-J $\mathrm{K}^{\mathrm{a}}$, 2차는 anti-D와 anti-K 항혈청 시약을 각각 희석하여 발송하였다.

\section{6) 시범항목}

1 회 때는 적혈구 $\mathrm{A} 1, \mathrm{H}$ 항원검사, 2회 때는 $\mathrm{ABO} \mathrm{Ab}$ 역가 검사를 실시하였다.

\section{7) 워크숍 개최}

혈액은행 실기 워크샵은 혈액은행분과 단독으로 주관하여 총 2 회의 워크숍을 개최하고자 하였다. 워크숍에 대한 공지는 개최 전에 홈페이지의 게시판과 문자수신 등을 이용하였다.

\section{3. 검체의 제조 및 우송}

모든 정도관리 검체는 기존의 방법처럼 [1-5] 아주대학교병 원 혈액은행에서 제조하였는데 혈구 검체는 대한적십자사에 
서 공급받은 citrate phosphate dextrose adenine- 1 혈액 백 에서 분리된 농축적혈구를 생리식염수 $10 \%$ 로 희석하였으며, 혈장 검체는 신선동결혈장을 냉동 보관한 후 무균봉합기로 연 결하여 혼합한 다음 분주하였다. 직접항글로불린검사용 검 체는 인간유래 다클론성 anti-D (DiaMed GmbH, Cressier $\mathrm{FR}$, Switzerland)를 사용하여 인위적으로 감작시킨 혈구 를 사용하였고, 교차시험용 검체는 동일 anti- $\mathrm{D}$ 를 폐기혈청 에 첨가하여 반응 역가를 결정하여 사용하였다. 또한 항체선 별 및 동정검사용 검체를 위하여 상품화된 인간유래 다클론 성 anti-D, 인간유래 다클론성 anti-Jk (Lorne laboratories limited, Berkshire, England), 단클론성인 anti-K (Lorne laboratories limited)를 폐기혈청에 첨가한 후 항글로불린 단 계에서의 혈구 응집 정도를 조절하여 제조하였다. 자가 제조된 모든 검체는 검사자 2 인이 각각 검사하여 결과 및 응집 정도를 확인하였다. 검체의 파손을 줄이기 위하여 에어 비닐을 이용하 여 검체를 포장하였고, 참여기관에 도착 전까지의 검체의 실온 노출기간을 최소화하기 위하여 제조 및 포장된 검체를 냉장 보 관하였다가 다음날 월요일에 일괄적으로 배송하였다.

Table 1. Number (responder \%) of participants for each test item of the survey in the 1st and 2nd trial

\begin{tabular}{llll}
\hline \multicolumn{1}{c}{ Survey item } & \multicolumn{1}{c}{ 2013-1* } & \multicolumn{1}{c}{ 2013-2 } & \multicolumn{1}{c}{ Mean } \\
\hline ABO grouping & $517(100.0)$ & $523(100.0)$ & $520(100.0)$ \\
RhD typing & $517(100.0)$ & $523(100.0)$ & $520(100.0)$ \\
Crossmatching & $467(90.3)$ & $472(90.2)$ & $470(90.2)$ \\
Direct antiglobulin test & $365(70.5)$ & $361(69.0)$ & $363(69.8)$ \\
Ab screening test & $274(53.0)$ & $275(52.5)$ & $275(52.7)$ \\
Ab identification test & $134(25.9)$ & $138(26.3)$ & $136(26.1)$ \\
\hline
\end{tabular}

Abbreviation: $\mathrm{Ab}$, antibody

${ }^{\star}$ Results of the 1 st trial. ${ }^{\dagger}$ Results of the 2 nd trial.

\section{결과}

\section{1. 신빙도조사 참여기관 수 및 회신율}

2013년 혈액은행검사 신빙도조사의 참여기관 및 회신율은 Table 1에 기술하였는데, 6 가지의 신빙도조사항목 중 한 종목 의 한 가지 검체라도 결과를 보낸 기관은 모두 포함시켰다. 검 체가 발송된 기관 수는 1 차(2차)가 548 기관(545기관)으로 평 균 547기관이었으며, 회신기관 수는 1차(2차)가 517 기관(523 기관)으로 평균 520 기관으로 회신율은 1차(2차)가 $94.3 \%$ (96.0\%)로 평균 $95.1 \%$ 였다.

조사항목별로 평균 회신기관 수를 살펴보면 $\mathrm{ABO}$ 혈액형 검사와 $\mathrm{RhD}$ 검사는 520 기관 $(100 \%)$, 교차시험은 470 기관 (90.2\%), 직접항글로불린검사는 363 기관(69.8\%), 항체선별 검사는 275 기관 $(52.7 \%)$, 그리고 항체동정검사는 136 기관에 서(26.1\%) 결과를 회신하였다(Table 1). 각 종목별 회신율은 예년과 유사하였다. 정답률 산정 시는 검사법이 다양하여 참여 기관의 수를 정확히 산정하기 곤란한 교차시험을 제외하고는 미입력기관은 오답으로 처리하였다.

\section{2. 조사항목}

\section{1) $A B O$ 혈액형검사}

$\mathrm{ABO}$ 혈액형검사는 2 차에 걸쳐 총 6 개의 검체로 실시하였 고, 1차는 99.6-100\%, 2차는 99.2-98.9\%의 정답률을 나타내 는데, 한 개의 검체라도 미입력을 보여 오답으로 간주된 기관 은 1 회차에 1 기관, 2 회차에 4 기관이었다(Table 2). 2회차의 경우 동일한 $\mathrm{O}$ 형 혈액형을 2 개 보내었는데, 두 번째 $\mathrm{O}$ 형의 정 답률이 $98.9 \%$ 로 작년이나 1 회차의 정답률에 비하여 낮고, 무 응답기관도 3 기관이나 되었다.

1차(2차)의 혈구형검사법은 슬라이드법이 $59.8 \%$ (60.2\%) 로 가장 많이 사용하는 방법으로 나타났으며, 그 뒤를 이어 시 험관법이 $39.2 \%$ (38.4\%)를 차지하였다. 1차(2차)의 혈청형검 사법은 혈구형과는 달리 시험관법이 $82.0 \%$ (83.6\%)로 가장

Table 2. Performance results of $\mathrm{ABO}$ grouping and $\mathrm{RhD}$ typing

\begin{tabular}{clccccc}
\hline Survey no. & Specimen & Participants & Correct answer (\%) & Specimen & Participants & Correct answer (\%) \\
\hline $2013-1$ & Group O & 517 & $517(100.0)$ & $\operatorname{RhD}(+)$ & $517\left(1^{\star}\right)$ & $515(98.4)$ \\
& Group A & $517\left(1^{\star}\right)$ & $515(99.6)$ & $\operatorname{RhD}(-)$ & $517\left(1^{\star}\right)$ & $515(98.4)$ \\
& Group B & 517 & $517(100.0)$ & $\operatorname{RhD}(+)$ & $517\left(2^{\star}\right)$ & $515(98.4)$ \\
$2013-2$ & Group O & 523 & $522(99.8)$ & $\operatorname{RhD}(+)$ & $523\left(2^{\star}\right)$ & $517(98.8)$ \\
& Group AB & $523\left(1^{\star}\right)$ & $519(99.2)$ & $\operatorname{RhD}(+)$ & $523\left(4^{\star}\right)$ & $516(98.6)$ \\
& Group O & $523\left(3^{\star}\right)$ & $517(98.9)$ & $\operatorname{RhD}(-)$ & $523\left(2^{\star}\right)$ & $519(99.2)$ \\
\hline
\end{tabular}

${ }^{\star}$ No. of non-responders. 


\section{Journal of LABORATORY MEDICINE and QUALITY ASSURANCE}

\section{Young Ae Lim et al • Annual Report on EQA in Blood Banks}

많이 사용하는 방법으로 나타났으며, 그 뒤를 이어 슬라이드법 이 $12.4 \%$ (11.8\%)이었으며, 마이크로웰 플레이트법은 $0.6 \%$ $(0.4 \%)$ 를 차지하였다(Table 3$). \mathrm{ABO}$ 혈액형검사의 혈청형 검사를 위해서 사용하는 적혈구는 1 차와 2 차는 회신기관의 $64.5 \%$ 와 $66.3 \%$ 에서 자가제조법으로 제조하여 사용하였다고 보고하였다.

\section{2) $\mathrm{RhD}$ 혈액형검사}

$\mathrm{RhD}$ 혈액형검사결과 1차는 $98.4 \%, 2$ 차는 $98.6-99.2 \%$ 의 정답률을 나타내었다(Table 2). 1차(2차)의 검사법은 $\mathrm{ABO}$ 혈액형검사법과 유사하게 슬라이드법이 $52.6 \%$ (53.7\%)를 차 지하여 가장 많이 사용하는 방법으로 나타났으며, 그 뒤를 이 어 시험관법 $45.2 \%$ (43.5\%)이었으며, 미세원주응집법 모두 $0.8 \%$ 를 차지하였다(Table 3 ).

Table 3. Number (\%) of participants of $\mathrm{ABO}$ and $\mathrm{RhD}$ typing according to the technique

\begin{tabular}{|c|c|c|c|c|c|c|}
\hline \multirow{3}{*}{ Technique } & \multicolumn{4}{|c|}{ ABO typing } & \multicolumn{2}{|c|}{ RhD typing } \\
\hline & \multicolumn{2}{|c|}{ 2013-1 } & \multicolumn{2}{|c|}{ 2013-2 } & \multirow{2}{*}{ 2013-1 (\%) } & \multirow{2}{*}{ 2013-2 (\%) } \\
\hline & Cell (\%) & Serum (\%) & Cell (\%) & Serum (\%) & & \\
\hline Slide & $309(59.8)$ & $64(12.4)$ & $315(60.2)$ & $60(11.4)$ & $272(52.6)$ & $281(53.7)$ \\
\hline Tube & $203(39.2)$ & $424(82.0)$ & $201(38.4)$ & 437 (83.6) & $234(45.2)$ & $228(43.5)$ \\
\hline Microwell & $3(0.6)$ & $3(0.6)$ & $3(0.6)$ & $2(0.4)$ & $3(0.6)$ & $4(0.8)$ \\
\hline Column agglutination technology & $2(0.4)$ & $2(0.4)$ & $3(0.6)$ & $2(0.4)$ & $4(0.8)$ & $4(0.8)$ \\
\hline No answer & $0(0.0)$ & $24(4.6)$ & $1(0.2)$ & $22(4.2)$ & $4(0.8)$ & $6(1.2)$ \\
\hline Total & 517 & 517 & 523 & 523 & 517 & 523 \\
\hline
\end{tabular}

Table 4. Performance results of cross matching

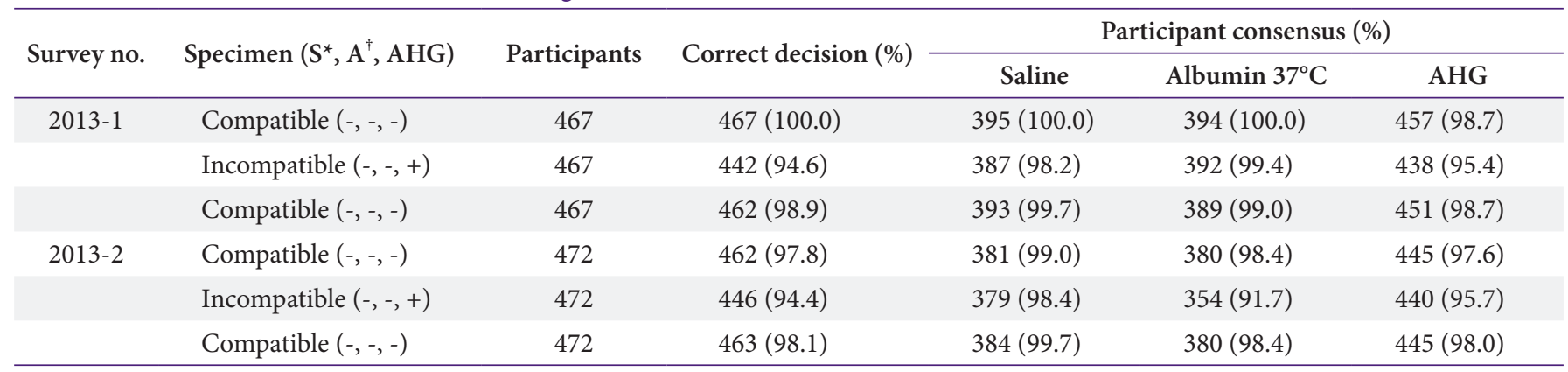

Abbreviation: AHG, anti-human globulin.

*Saline or low ionic strength saline at room temperature. ${ }^{\dagger} 37^{\circ} \mathrm{C}$ incubations with addition of albumin or none.

Table 5. Performance results of direct antiglobulin test

\begin{tabular}{|c|c|c|c|c|c|c|c|}
\hline \multicolumn{2}{|c|}{ Result } & \multicolumn{2}{|c|}{$\begin{array}{c}\text { Polyspecific anti-human } \\
\text { globulin }\end{array}$} & \multicolumn{4}{|c|}{ Monospecific } \\
\hline Survey no. & $\left(\mathrm{P}^{\star}, \mathrm{G}^{\dagger}, \mathrm{C}^{\ddagger}\right)$ & No. ${ }^{5}$ & $\%$ & No. ${ }^{\S}$ & $\%$ & No..$^{\S}$ & $\%$ \\
\hline \multirow[t]{2}{*}{ 2013-1 } & $(+,+,-)^{\|}$ & $345 / 365$ & 94.5 & $71 / 75$ & 94.7 & $63 / 69$ & 91.3 \\
\hline & $(-,-,-)^{\|}$ & $358 / 362$ & 98.9 & $73 / 74$ & 98.6 & $66 / 68$ & 97.0 \\
\hline 2013-2 & $(+,+,-)^{\|}$ & $350 / 361$ & 97.0 & $78 / 82$ & 95.1 & $69 / 75$ & 92.0 \\
\hline
\end{tabular}

${ }^{*}$ Polyspecific anti-human globulin. ${ }^{\dagger}$ Anti-IgG. ${ }^{~}$ Anti-C3d. ${ }^{\varsigma}$ Institute’s no. with correct answer/participants' no. ${ }^{\prime \prime}+$, positive; -, negative 


\section{Young Ae Lim et al • Annual Report on EQA in Blood Banks}

\section{3) 교차시험검사}

교차시험검사는 2 차에 걸쳐 총 6 개의 검체가 사용되었으 며, 1차는 94.6-100.0\%, 2차는 94.4-98.1\%에서 정답률을 보 였다. 적합 및 부적합 검체에 대하여 각 단계별 정답률을 분석 한 결과, 적합 검체가 97.8-100.0\%이고, 부적합 검체가 94.4$94.6 \%$ 로 부적합 검체에서 오답률이 더 높았다(Table 4). 검 사법은 시험관법이 1차(2차)가 각각 $83.7 \%$ (81.4\%)로 가장 많이 사용하는 방법으로 나타났으며, 미세원주응집법 $14.8 \%$ (16.9\%), 마이크로웰 플레이트법 모두 $0.2 \%$ 씩을 차지하였으 며, 응답을 하지 않은 기관도 $1.3 \%$ (1.5\%)를 차지하였다.

\section{4) 직접항글로불린검사}

직접항글로불린검사는 2 차에 걸쳐 총 4 개의 검체가 사용 되었는데, 다특이성 항글로불린법의 1차(2차)의 정답률은 양 성 검체 $94.5 \%$ (97.0\%)였으며, 음성 검체는 98.9\% (99.7\%) 로 양성 검체에 대한 오답률이 더 높은 것으로 분석되어 예년 과 동일한 양상을 보였다. 1차(2차)의 $\operatorname{IgG}$ 단특이성 항글로 불린을 사용한 경우 음성이었던 검체에 대한 정답률은 $98.6 \%$ (98.6\%)로 양성이었던 검체에 대한 정답률 $94.7 \%$ (95.1\%)에 비하여 높았다. 반면 C3d 단특이성 항글로불린을 사용한 경
우는 모두 음성이었는데 1차(2차)의 정답률은 다특이성 항글 로불린법이 양성인 검체인 경우 $91.3 \%$ (92.0\%)로 IgG 단특 이성 항글로불린검사 검체의 정답률에 비하여 낮았다(Table 5). 검사법은 시험관법이 1차(2차)가 각각 $53.6 \%$ (51.5\%) 로 가장 많이 사용하는 방법으로 나타났으며, 미세원주응집법 $45.3 \%$ (47.2\%), 마이크로웰 플레이트법 모두 $0.5 \%$ 씩을 차지 하였으며, 응답을 하지 않은 기관도 $0.6 \%$ (0.8\%)를 차지하였 다.

5) 비예기항체 선별 및 동정검사

항체선별검사의 정답률은 음성 검체 99.2-100.0\%, 양성 검체 90.9-100.0\%를 나타내었고, 항체동정검사의 정답률은 anti-D는 $100.0 \%$, anti-K는 $97.1 \%$ 를 나타내었으나, anti-JK ${ }^{\mathrm{a}}$ 는 $87.3 \%$ 로 정답률이 낮았다(Table 6). 미입력기관도 anti$\mathrm{JK}^{\mathrm{a}}$ 9기관, anti-K 4 기관 모두 오답으로 처리하였다. 1차(2차) 의 항체선별검사법은 미세원주응집법이 $87.6 \%(87.3 \%)$ 로 가 장 많이 사용하는 방법으로 해마다 사용기관이 증가하고 있 으며, 시험관법 9.9\% (10.1\%), 마이크로웰 플레이트법이 모 두 $2.2 \%$ 를 차지하였다. 1차(2차)의 항체동정검사법도 항체선 별검사법과 유사한 양상을 보였는데 미세원주응집법 $92.7 \%$

Table 6. Performance results of unexpected antibody screening and identification tests

\begin{tabular}{|c|c|c|c|c|c|c|}
\hline \multirow{2}{*}{ Survey no. } & \multirow{2}{*}{ Specimen } & \multicolumn{2}{|c|}{ Screening } & \multicolumn{3}{|c|}{ Identification } \\
\hline & & Participants & Correct answer (\%) & Antibody & Participants & Correct answer (\%) \\
\hline \multirow[t]{2}{*}{ 2013-1 } & Positive & 274 & $274(100.0)$ & Anti-D & 134 & $134(100.0)$ \\
\hline & Positive & 154 & $140(90.9)$ & Anti-Jk ${ }^{\mathrm{a}}$ & $134\left(9^{*}\right)$ & $117(87.3)$ \\
\hline \multirow[t]{2}{*}{ 2013-2 } & Positive & 275 & 273 (99.3) & Anti-D & 138 & $138(100.0)$ \\
\hline & Positive & 156 & $153(98.1)$ & Anti-K & $138\left(4^{*}\right)$ & $134(97.1)$ \\
\hline
\end{tabular}

${ }^{\star}$ No. of non-responders.

Table 7. Number (\%) of participants of unexpected antibody screening and identification tests according to the technique

\begin{tabular}{|c|c|c|c|c|}
\hline \multirow{2}{*}{ Technique } & \multicolumn{2}{|c|}{ Antibody screening } & \multicolumn{2}{|c|}{ Antibody identification } \\
\hline & 2013-1 (\%) & 2013-2 (\%) & 2013-1 (\%) & 2013-2 (\%) \\
\hline Column agglutination technology & $240(87.6)$ & $233(87.3)$ & $125(92.7)$ & $134(95.0)$ \\
\hline Tube & $27(9.9)$ & $27(10.1)$ & $8(5.9)$ & $6(4.3)$ \\
\hline Microwell & $6(2.2)$ & $6(2.2)$ & $1(0.7)$ & $1(0.7)$ \\
\hline No answer & $1(0.3)$ & $1(0.4)$ & $1(0.7)$ & 0 \\
\hline Total & $274(100.0)$ & $267(100.0)$ & $135(100.0)$ & $141(100.0)$ \\
\hline
\end{tabular}


(95.0\%)로 가장 많이 사용하는 방법으로 나타났으며, 시험관 법 $5.9 \%(4.3 \%)$, 마이크로웰 플레이트법 모두 $0.7 \%$ 를 차지 하였다(Table 7). 비예기항체 선별검사를 위해서 사용하는 적 혈구는 1차(2차)의 회신기관의 $2.9 \%$ (1.5\%), 동정검사는 모 두 회신기관의 $2.2 \%(0.0 \%)$ 에서 자가제조법으로 제조하였다 고 보고하였다.

\section{6) 시범항목}

적혈구 $\mathrm{A} 1, \mathrm{H}$ 항원은 1 차 때만 실시하였는데 $\mathrm{A} 1$ 과 $\mathrm{O}$ 형 의 2 개의 검체에 대하여 각각 58 개 기관과 60 개의 기관이 응 답하여 $\mathrm{ABO}$ grouping 참여기관인 517 기관의 각각 $11.2 \%$ 와 $11.6 \%$ 가 참여하였다. 2012년도 62-67기관에 비하여 참여기 관의 수는 감소하였다. 정답은 전년도와 마찬가지로 $\mathrm{A} 1$ 검체 의 경우 $\mathrm{A} 1$ 항원검사는 $2+$ 이상, $\mathrm{H}$ 항원검사는 $1+$ 이하, $\mathrm{O}$ 검체의 경우 $\mathrm{A} 1$ 항원검사는 음성, $\mathrm{H}$ 항원검사는 $2+$ 이상으로

Table 8. Results of antigen testing for the presence of Aland $\mathrm{H}$ antigens

\begin{tabular}{llccc}
\hline \multirow{2}{*}{ ABO result } & \multicolumn{2}{c}{ O (R1) participants (\%) } & \multicolumn{2}{c}{ A1 (R2) participants (\%) } \\
\cline { 2 - 5 } & Anti-A1 & Anti-H & Anti-A1 & $1(1.7)$ \\
Negative & $60(100.0)$ & $1(1.7)$ & $8(13.8)$ & $12(72.4)$ \\
Trace-1+ & 0 & $1(1.7)$ & $13(22.4)$ & 0 \\
$2+$ & 0 & $3(5.0)$ & $14(24.1)$ & 0 \\
$3+$ & 0 & $4(6.6)$ & $22(38.0)$ & $1(1.7)$ \\
$4+$ & 0 & $51(85.0)$ & $58(100.0)$ & $58(100.0)$ \\
Total & $60(100.0)$ & $60(100.0)$ &
\end{tabular}

$\mathrm{R} 1$ and $\mathrm{R} 2$ are the proficiency testing specimens for $\mathrm{ABO}$ and RhD typing.

Table 9. Number of participants for the results of ABO antibody titration according to the technique

\begin{tabular}{|c|c|c|c|c|c|c|c|c|c|c|c|c|c|}
\hline Techniques & $\mathrm{N}$ & Negative & $1: 1$ & $1: 2$ & $1: 4$ & $1: 8$ & $1: 16$ & $1: 32$ & $1: 64$ & $1: 128$ & $1: 256$ & $1: 512$ & $1: 1024 \leq$ \\
\hline \multicolumn{14}{|l|}{ Anti-A } \\
\hline Tube-IS $(60.5 \%)^{*}$ & 43 & 1 & 1 & 2 & 1 & 5 & $6^{\dagger}$ & 14 & 6 & 4 & 1 & 1 & 1 \\
\hline Tube-RT $(83.3 \%)^{\star}$ & 12 & 0 & 1 & 0 & 0 & 1 & 3 & 3 & 4 & 0 & 0 & 0 & 0 \\
\hline Tube-AHG $(58.8 \%)^{\star}$ & 17 & 0 & 0 & 1 & 0 & 0 & 3 & 2 & 3 & 5 & 2 & 0 & 1 \\
\hline CAT-RT & 6 & 0 & 0 & 0 & 1 & 0 & 1 & 2 & 2 & 0 & 0 & 0 & 0 \\
\hline CAT-AHG $(93.3 \%)^{*}$ & 15 & 1 & 0 & 0 & 0 & 0 & 0 & 0 & 2 & 5 & 5 & 2 & 0 \\
\hline DTT treatment & 8 & 0 & 1 & 0 & 0 & 1 & 0 & 0 & 3 & 1 & 2 & 0 & 0 \\
\hline Other & 2 & 0 & 0 & 1 & 0 & 0 & 0 & 0 & 0 & 0 & 1 & 0 & 0 \\
\hline \multicolumn{14}{|l|}{ Anti-B } \\
\hline Tube-IS $(69.0 \%)^{*}$ & 42 & 1 & 2 & 0 & 4 & 7 & 15 & 7 & 2 & 2 & 2 & 0 & 0 \\
\hline Tube-RT $(83.3 \%)^{*}$ & 12 & 1 & 0 & 0 & 0 & 1 & 3 & 7 & $\mathbf{0}$ & 0 & 0 & 0 & 0 \\
\hline Tube-AHG $(70.6 \%)^{*}$ & 17 & 0 & 1 & 0 & 0 & 0 & 3 & 2 & 6 & 4 & 0 & 0 & 1 \\
\hline CAT-RT & 6 & 1 & 0 & 0 & 0 & 1 & 3 & 1 & 0 & 0 & 0 & 0 & 0 \\
\hline CAT-AHG $(80.0 \%)^{*}$ & 15 & 0 & 1 & 0 & 0 & 0 & 1 & 0 & 7 & 5 & 1 & 0 & 0 \\
\hline DTT treatment & 8 & 0 & 0 & 1 & 0 & 0 & 1 & 3 & 3 & 0 & 0 & 0 & 0 \\
\hline Other & 2 & 0 & 0 & 0 & 1 & 0 & 0 & 0 & 0 & 0 & 1 & 0 & 0 \\
\hline
\end{tabular}

Abbreviations: IS, immediate spin; RT, room temperature incubation; AHG, indirect anti-human globulin test; CAT, column agglutination technology; DTT, dithiothreitol.

${ }^{*}$ Percentage of participants within allowable range. ${ }^{\dagger}$ Bold characters express allowable range for ABO antibody titer. 


\section{Journal of LABORATORY MEDICINE and QUALITY ASSURANCE}

\section{Young Ae Lim et al • Annual Report on EQA in Blood Banks}

간주하였다. $\mathrm{A} 1$ 검체의 경우 $\mathrm{A} 1$ 항원검사는 $84.5 \%, \mathrm{H}$ 항원검 사는 $98.3 \%$ 에서 정답을 보여 전년도 $97 \%$ 와 $98.4 \%$ 의 정답률 에 비하여 오히려 감소하였다. 그러나 $\mathrm{O}$ 검체의 경우 $\mathrm{A} 1$ 항원 검사는 $100.0 \%, \mathrm{H}$ 항원검사는 $96.6 \%$ 에서 정답을 보여 전년 도 $91 \%$ 와 $85.7 \%$ 에 비하여 높았다(Table 8).

2012년에 용역과제연구로 2회에 실시되었던 ABO 항체역 가검사는 2013년에는 2회차에만 1회 실시되었는데, 각 방법별 참여기관의 수와 결과는 Table 9 와 같다. IgM 측정을 위하여 2012년 표준안으로 제시된 시험관 실온배양법에 비하여 시험 관 즉시원침법을 사용하는 기관이 더 많았고, $\operatorname{IgG}$ 측정을 위해 서는 시험관 항글로불린법 17 기관, 미세원주응집법 항글로불 린법 15 기관이었다. 각 항체의 허용범위는 최빈도역가 \pm 1 배수 (혹은 허용범위가 2 역가인 경우는 로그 평균값 방향 1 배수를 추가함)로 정의하였고, 결과 입력기관이 10 기관 이상인 경우 만 분석하여 Table에는 굵은 글씨로 표시하였다. 허용범위 산 정에 대해서는 설명문을 홈페이지에 게시하였다. 허용범위에 드는 참여기관 비율은 시험관 즉시 원침법은 $60.5-69.0 \%$, 시 험관 실온배양법 $83.3 \%$, 시험관 항글로불린법 58.8-70.6\%였 으며, 미세원주응집 항글로불린법이 80.0-93.3\%로 가장 일치 율이 높았다.

\section{3. 워크숍 개최}

1 차는 $\mathrm{ABO}$ 혈액형 실기 워크숍으로 2013년 7월 5일(금) 오 후 1 시부터 3 시까지 아주대학교 의과대학 송재관 학생실습실 에서 $\mathrm{ABO}$ 아형, $\mathrm{D}$ 변이형 검체검사 검출법에 대한 강의와 실 습이 이루어졌으며 총 58명이 등록하여 참석하였다. 비예기항 체검사에 대한 2차 워크숍은 2013년 8월 30일(금) 오후 1시부 터 3시까지 아주대학교 의과대학 송재관 학생실습실에서 교차 검사, 비예기항체 선별과 동정에 대한 강의와 실습이 이루어 졌으며, 총 60명이 등록하여 참석하였다. 2013년에는 각 실기 워크솝에 대하여 1 회씩만 실시하여 작년에 비하여 참가인원은 일부 감소하였다.

\section{고찰}

2013년 혈액은행검사 신빙도조사의 참여 회신율은 2012년 도 512 기관에 비하여 참가기관은 $1.5 \%$ 증가하였고, 회신율은 2011년 98.2\%, 2012년 97.1\%에 비하여 점점 감소하는 경향 을 보였다 [1,2]. 이러한 현상은 신청은 하였으나 참여의사가 높지 않았던 기관들 때문인 것으로 여겨졌다. 따라서 향후 정 도관리 사업비를 지불하여 참여의사를 확실히 보인 기관에게만 검체를 발송할 예정이므로 회신율도 증가할 것으로 여겨졌다.
2 회차의 경우 $\mathrm{O}$ 형 검체를 2 개 발송하였는데, 이 중 두 번째 검체의 정답률이 첫 번째 $\mathrm{O}$ 형 검체에 비하여 정답률도 낮고 무응답을 보인 기관도 있었다. 이는 이유는 아마도 두 번째 $\mathrm{O}$ 형의 검체를 $\mathrm{ABO}$ 아형의 검체로 간주한 기관이 일부 있었기 때문에 결과에 영향을 미친 것으로 생각되었다. 따라서 혈액형 신빙도조사 시 동일한 혈액형을 보내는 것도 혈액은행검사실 의 질을 평가할 수 있는 좋은 방안으로 여겨졌다.

$\mathrm{RhD}$ 정답률이 전년도에 비하여 낮았는데, 이는 미입력기관 이 증가하였기 때문인 것으로 추정되었다. 미입력은 답변이 까 다롭다고 여겨지는 경우 참여기관들이 고의로 입력하지 않거 나 혹은 사무적 착오일 수 있다. 자동화 장비로 결과가 자동 전 송되는 검사들과는 달리 혈액형검사의 경우 국내 대부분의 검 사실이 수기법으로 시행하여 결과를 입력하여야 하므로, 사무 적 착오를 점검하는 것은 매우 중요하다고 할 수 있다.

교차시험의 경우 부적합 검체의 정답률이 기존에 비하여 낮 았는데, 이는 아마도 실온식염수법에서부터 양성을 보였던 검 체를 항상 포함하였던 기존의 검체와는 달리 2013년도 1차와 2 차 검체에는 이러한 검체는 포함하지 않고, 모두 항글로불린 법에서만 응집을 보였던 검체만을 포함하였기 때문인 것으로 분석하였다. 직접항글로불린검사의 경우 $\mathrm{C} 3 \mathrm{~d}$ 단특이성 항글 로불린검사는 음성임에도 불구하고 양성이라고 보고한 기관 들은 다특이성 혹은 $\mathrm{IgG}$ 단특이성 직접항글로불린검사의 결 과가 양성인 경우 함께 양성으로 보고한 것으로 이들에 대한 바이어스 영향을 받은 것으로 해석되었다. 따라서 오답기관은 $\mathrm{C} 3 \mathrm{~d}$ 단특이성 항글로불린 시약을 재검토하거나 혹은 이의 검 사방법이나 해석에 대한 재교육이 필요한 것으로 판단되었다. 또한 직접항글로불린 검사법으로 2008 년 $63.6 \%$ 였던 시험관 법은 점점 감소하면서 2008 년 $32.4 \%$ 였던 미세원주응집법이 점점 증가하고 있음을 알 수 있었다[5].

비예기항체 선별 및 동정검사에 사용된 anti-K는 $97.1 \%$ 의 높은 정답률을 보인 반면 anti-JK $\mathrm{K}^{\mathrm{a}}$ 는 $87.3 \%$ 로 낮은 정답률을 보인 이유는 anti-Jk 검체는 희석된 인간유래 다클론항체로 동물유래 단클론항체 IgM에 비하여 항체 역가가 낮고 혈구응 집능 반응이 약하기 때문인 것으로 분석되었다. 그러나 이러한 특성은 반응이 강한 단클론항체 IgM에 비하여 오히려 환자 검 체에 가깝기 때문에 고가이기는 하나 향후에도 인간유래 다클 론항체를 검체를 계속 외부정도관리물질로 사용할 필요가 있 다고 여겨졌다.

혈액은행 장비의 자동화검사법에 대한 검사방법 입력코드 는 미세원주응집법만이 있었으나 국내에서도 최근에는 이 이 외에도 자동화가 가능한 고형상적혈구부착법 (solid phase red cell adherence assay)과 적혈구자기화법(erythrocyte- 
magnetized technique)이 소개되고 있으므로 2014년 사업부 터는 검사법 입력코드에 이에 대한 검사방법의 코드 신설이 필 요할 것으로 여겨졌다.

시범항목인 적혈구 $\mathrm{A} 1, \mathrm{H}$ 항원검사에 참여한 기관 수는 2012 년도에 비하여 감소하였다. 적혈구 $\mathrm{A} 1, \mathrm{H}$ 항원검사에 사 용되는 시약은 3등급 체외진단제품으로 2012년 12월까지 식 품의약품안전처 허가를 득하여야 국내에 시약 공급이 가능하 다. 그러나 불행히도 저자들이 확인한 바로는 아직까지 $\mathrm{H}$ 항 원검사 시약에 대한 식품의약품안전처 허가를 득한 국내 업체 가 없는 실정이다. 이러한 현상은 이 시약들은 국내 사용량이 매우 적어 업체들이 이득을 볼 수 없는 시약인데다가 식품의약 품안전처 허가절차나 이에 소요되는 비용이 크기 때문에 허가 를 받으려는 기관들이 없기 때문인 것으로 분석되었다. 그러나 혈액은행검사에 사용되는 상당수 시약들이 사용량이 매우 적 어 업체들은 이득을 볼 수 없지만 환자의 올바른 혈액형 판정 이나 항체동정 등에 필수적이라는 특징이 있다. 이러한 시약들 없이는 결국 환자들에게 올바른 수혈 혈액을 제공해주지 못할 수도 있어 환자의 안전과도 직결되는 문제라 할 수 있다. 따라 서 환자들의 안전을 위하여 이러한 희귀 시약들에 대하여 무조 건적으로 허가만을 강요하는 제도는 다시금 검토될 필요가 있 다고 여겨지며, 이득이 되지 않는다고 허가과정을 포기하는 업 체들도 독려하여 허가에 참여하도록 유도할 필요가 있을 것으 로 여겨졌다.

\section{REFERENCES}

1. Lim YA, Oh JS, Kwon SW, Kwon KC, Kim SY, Park KU, et al. Annual report on external quality assessment in blood bank tests in Korea (2012). J Lab Med Qual Assur 2013; 34(S1):S103-S15.

2. Lim YA, Oh JS, Kwon SW, Kwon KC, Kim SY, Park KU, et al. Annual report on external quality assessment in blood bank tests in Korea (2011). J Lab Med Qual Assur 2012; 33(S1):S91-S104.

3. Lim YA, Oh JS, Kwon SW, Kwon KC, Kim SY, Park KU, et al. Annual report on external quality assessment in blood bank tests in Korea (2010). J Lab Med Qual Assur 2011;33(S1):S75-S89.

4. Kwon SW, Kim DW, Han KS, Kim HO, Seo JS, Cha YJ, et al. Annual report on external quality assessment in blood bank tests in Korea (2009). J Lab Med Qual Assur 2010; 32:95-101.

5. Kwon SW, Kim DW, Han KS, Kim HO, Seo JS, Cha YJ, et al. Annual report on external quality assessment in blood bank tests in Korea (2008). J Lab Med Qual Assur 2009; 31:99-104. 
혈액은행분과 신빙도조사 결과보고(2013)

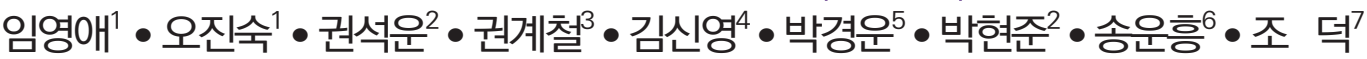
엄태현 ${ }^{8}$ 허 광 ${ }^{9}$ 한상무 ${ }^{10}$ - 대한임상검사정도관리협회 혈액은행분과위원회 ${ }^{1}$ 아주대학교병원 진단검사의학과, ${ }^{2}$ 서울아산병원 진단검사의학과, ${ }^{3}$ 충남대학교병원 진단검사의학과, ${ }^{4}$ 세 브란스병원 진단검사의학과, ${ }^{5}$ 분당서울대학교병원 진단검사의학과, ${ }^{6}$ 신한대학교 임상병리학과, ${ }^{7}$ 화순전남 대학교병원 진단검사의학과, ${ }^{8}$ 인제대학교일산백병원 진단검사의학과, ${ }^{9}$ 대한적십자사 중앙혈액검사센터, ${ }^{10}$ 대한적십자사 경기혈액원

2013년에 시행된 혈액은행검사에 대한 신빙도조사결과를 분석하였다. 검체는 아주대학교병원에서 직접 제조하였으며, 검체 발송기관 수는 1차 548 기관과 2차 545 기관이다. 평가종목은 $\mathrm{ABO}$ 혈액형

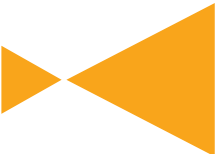

Journal of LABORATORY MEDICINE and

QUALITY ASSURANCE 검사, $\mathrm{RhD}$ 혈액형검사, 교차시험검사, 직접항글로불린검사, 비예기항체 선별검사 및 동정검사였다. 검체 발송기관에 대한 1차와 2 차의 회신율은 각각 $94.3 \%$ 와 $96.0 \%$ 였다. 미입력은 오답으로 처리하 였고, 평가종목에 대한 평균 정답률은 다음과 같았다. $\mathrm{ABO}$ 혈액형검사 $98.9-100 \%, \mathrm{D}$ 혈액형검사 98.4-99.2\%, 교차시험검사 94.4-100.0\%, 다특이성 직접항글로불린검사 94.5-99.7\%; $\operatorname{lgG}$ 단특 이성 직접항글로불린검사 94.7-98.8\%, C3d 단특이성 직접항글로불린검사 91.3-98.6\%, 항체선 별검사 90.9-100\%, 항체동정검사 87.3-100\%이었다. 2013년도 혈액은행검사 신빙도결과는 전 반적으로 우수한 편이었으며 참여기관의 수는 2012년도에 비하여 더 확대되었다.

(J Lab Med Qual Assur 2014;36:55-63)

\section{교신저자: 임영애}

우) 443-380 경기도 수원시 영통구 월드컵로 164, 아주대학교 의과대학 진단검사의학과

Tel: 031)219-5786, Fax: 031)219-5778, E-mail: limyoung@ajou.ac.kr 